\title{
A Time to Reflect
}

\author{
Douglas McDougall ${ }^{1}$
}

Accepted: 29 November 2021/Published online: 5 January 2022

(C) Ontario Institute for Studies in Education (OISE) 2022

There are many times in the year when we should pause to reflect on what has happened over a period of time. The end of a calendar year is one time when most of us think back to what we have done over the past year and even think about what we might do in the following year. This is a rather unique issue. All but one of the articles is from researchers in Canadian universities. We invite you to write a response to one of the articles to further engage with the themes and issues in Science, Mathematics and Technology Education.

Chorney and Bakos (2021) investigated storylines of how non-Indigenous pre-service teachers conceive the call to incorporate First Peoples' worldviews and perspectives into their mathematics teaching. These pre-service teachers are enrolled in an undergraduate teacher preparation course that explores how Indigenous knowledge, pedagogies and perspectives can be aligned with the teaching of mathematics. The students' written reflections from the start and end of the course were examined using positioning theory to identify patterns and themes. Chorney found examples of mathematics reframing, retemporalising and repersonalising. These pre-service teachers were willing to rethink their personal positions. There are many challenges to indigenising mathematics teacher education. This research can help pre-service teachers and university instructors engage in productive conversations about how to support non-Indigenous prospective teachers.

Husband (2021) investigated pre-service teachers as they engaged in a 10-day professional development course after completing their teacher education program. The teachers were asked to complete some elementary school mathematics tasks. Videos and teacher journals were analysed using Pirie and Kieren (1994) Theory for the Dynamical Growth of Mathematical Understanding. In this article, Husband focuses on the pre-service teacher's understanding of subtraction. He found that it was challenging for the teachers to unpack and work with existing mathematics knowledge. The process required patient observation and timely interventions that involved a lot of time and teaching strategies. This research shows that prospective teachers need additional professional development courses and activities to explore and grow their understanding of elementary mathematics.

Douglas McDougall

doug.mcdougall@utoronto.ca

1 Ontario Institute for Studies in Education, University of Toronto, Toronto, Ontario M5S 1V6, Canada 
Throope Robinson et al. (2021) investigate a two-year professional development certificate program to enhance teacher capacity for teaching mathematics in elementary schools. Their mixed methods study used an online survey and teacher interviews to determine the effectiveness of the program and to gauge teacher preparedness to become leaders in mathematics education. Three themes were identified: professional development and content knowledge, leadership and culturally responsive pedagogy. One of their goals was to build capacity among teachers, and they noted that regular conversations with teachers are necessary to sustain positive relationships and to build a network. They recognized the importance of focused training for instructors in differentiating instruction and assessment and to better understand the talents and experiences that students bring to the classroom. There are many ways to build teacher leadership capacity in elementary schools, and this certificate program has shown success in developing leaders in mathematics education.

Saldana and Hatfield (2021) investigated the use of TinkerPlots software to organize data sets with Grade 7 students. The instructional sequence was intended to help the students to understand the location of quarters of the data within the range of the full set and the spread of those portions. The students were given a pre-test and then assigned a culminating task to create hypothetical data from a box plot. They found that students would confuse the significance of a quarter's location with the spread. This shows that the students' attention was not focused equally on both the location and the spread of data portions. This research helps us to better understand the instructional tasks that can be used to orient students' attention in data location and spread.

Anwandter Cuellar et al. (2021) present the results of research on algebraic thought of 3- to 8-yearold children. The results show that there are conceptual problems to characterize algebraic thinking. That is, there is not a consistent and common definition of algebraic thinking in young children. There is, however, great potential of young children to understand aspects of algebraic thinking. This article illustrates that there are still many unanswered questions about how and when early algebraic thinking develops in 3- to 8-year olds.

In the special theme of the 21.2 issue, there are articles that focused on "Responding to AntiBlack Racism in Science, Mathematics, Technology and STEM Education". In a continuation of that theme, Davis (2021) examines the mathematics education enterprise to illustrate how whiteness and antiBlackness have been normalized. He describes his personal and professional journey to learn about and work towards Black liberation in global Black communities and how this experience has informed his approach to Black liberation in mathematics education. He states that liberation in mathematics education is a complicated endeavour, and he provides insight and suggestions on how to help Black adults and students better understand the historical and current situation in mathematics education.

Larsen and Jang (2021) examined the effects of direct instruction and inquiry learning on mathematics achievement of elementary school students and how self-efficacy mediated this achievement. The study also investigated how students with an IEP (Individual Education Plan) status affected this relationship. They found that inquiry learning was positively associated with student self-efficacy while direct instruction was negatively associated with self-efficacy. These results suggest that inquiry learning is beneficial for students with special needs and that we should encourage teachers to use inquiry learning with all students to enhance their achievement in mathematics. This study provides additional evidence that teachers should be using a variety of instructional strategies in their classrooms.

Chernoff (2021) continues his new regular viewpoint in mathematics education. In this issue, he writes about Gmail's Mail Googles through a potential research project. Mail Googles are a feature of Gmail that was intended to prevent people from emailing under the influence of alcohol. He details the grade equivalent for the math skills necessary to get past the Mail Googles for an inebriated, adult Canadian. Mail Googles are a feature of Gmail that was intended to prevent people from emailing 
under the influence of alcohol. Mail Googles would send you some math problems to solve and, if you were successful, you could send out your email. Chernoff proceeds to determine the grade level equivalent of the problems, with references to Mad Minutes of mathematics calculations. I invite you to take a journey with Egan Chernoff, mathematics editor (English) as he unravels what he found in that folder on his computer. Check back in a few months for issue 22.1 where Egan Chernoff will return with other Canadian mathematics education matters.

Pyper (2021) reviews the book Borders in Mathematics Pre-Service Teacher Education (Radakovic and Jao 2020). He notes that the book explores borders with curricula, teacher education programs and interactions with society. He uses Activity Systems to interpret each chapter and, in many cases, providing graphic representation of the tensions that exist between various aspects of the Activity System. He also investigates borderlands, the spaces that are close to the borders. It is in these spaces that there are opportunities for discussion and actions to remove or bridge a border. Pyper contends that uncovering tensions in an activity system could provide insights into a critical thinking of mathematics education using the lens of borders. The book authors encourage readers to challenge the borders in mathematics education and to consider how these chapters can be extended beyond the borders.

\section{Declarations}

Conflict of Interest The author declares no competing interests.

\section{References}

Anwandter Cuellar, N., Polotskaia, E., \& Passaro, V. (2021). La Genése de la pensée algébrique chez les enfants de trois à huit ans. Une revue de la littérature scientifique. Revue canadienne d'enseignement des sciences, des mathématiques et des technologies, 21(4).

Chernoff, E.J. (2021). Looking back at gmail's mail googles: my most maddest of mad minutes. Canadian Journal of Science, Mathematics and Technology Education, 21(4). https://doi.org/10.1007/s42330-021-00186-y

Chourney, S. \& Bakos, S. (2021). Investigating the positioning of pre-service teachers in relation to incorporating First Peoples' worldviews into mathematics teaching. Canadian Journal of Science, Mathematics and Technology Education, 21(4). https://doi.org/10.1007/s42330-021-00180-4

Davis, J. (2021). A liberatory response to antiblackness and racism in the mathematics education enterprise. Canadian Journal of Science, Mathematics and Technology Education, 21(4). https://doi.org/10.1007/s42330-021-00187-x

Husband, M. (2021). Prospective teachers working to connect their own understanding of subtraction. Canadian Journal of Science, Mathematics and Technology Education, 21(4). https://doi.org/10.1007/s42330-021-00179-x

Larsen, N. E., \& Jang, E. E. (2021). Instructional practices, students' self-efficacy and math achievement: A multi-level factor score path analysis. Canadian Journal of Science, Mathematics and Technology Education, 21(4). https://doi. org/10.1007/s42330-021-00181-3

Pirie, S., \& Kieren, T. (1994). Growth in mathematical understanding: How can we characterize it and how can we represent it? In P. Cobb (Ed.), Learning mathematics: Constructivist and interventionist theories of mathematical development (pp. 61-86). Dordrecht, NL: Kluwer.

Pyper, J. (2021). Tensions in the borderlands: a review of borders in mathematics pre-service teacher education. Canadian Journal of Science, Mathematics and Technology Education, 21(4). https://doi.org/10.1007/s42330-021-00182-2

Radakovic, N. \& Jao, L. (2020). Borders in Mathematics Pre-Service Teacher Education. Springer.

Saldanha, L. \& Hatfield, N. (2021). Students conceptualizing the box plot as a tool for structuring quantitative data: a design experiment using TinkerPlots. Canadian Journal of Science, Mathematics and Technology Education, 21(4). https://doi.org/10.1007/s42330-021-00184-0

Throope Robinson, E., Lunney Borden, L., \& Carter, E. (2021). Building teacher capacity and leadership in elementary mathematics classrooms in Nova Scotia: Review of the certificate in elementary mathematics pedagogy. Canadian Journal of Science, Mathematics and Technology Education, 21(4). https://doi.org/10.1007/s42330-021-00183-1

Publisher's Note Springer Nature remains neutral with regard to jurisdictional claims in published maps and institutional affiliations. 